\title{
DRYING AND STERILIZATION OF HIGH MOISTURE ROUGH RICE USING CONDUCTION HEATING ROTARY DRYER.
} Matouk, M. M. ${ }^{1}$; M. M. El-Kholy ${ }^{2}$; A. Thanwat ${ }^{3}$ and Al-Shaimaa.M. Shabban ${ }^{4}$ 1- Prof. of Agric. Eng. Agric Eng. Dept. Fac. of Agric. Mansoura Univ.

2- Prof \&Head, Div. of Handling and Processing of Agric. Crops, Agric .Eng. Res. Institute.

3- Lectural of Agric. Eng. Dept. Fac. of Agric., Mansoura University. 4- Post graduate student, Agric. Eng. Dept. Fac. of Agric., Mansoura Univ.

\begin{abstract}
A study was carried out to test and evaluate the effect of high-temperature short time conduction heating process using a laboratory scale rotary dryer on sterilization and drying of high moisture rough rice and quality changes of milled rice. The experimental treatments included five different levels of heating surface temperature $\left(105,115,125,135\right.$ and $\left.145^{\circ} \mathrm{C}\right)$ and two different grain feed rates $(2.5$ and $3 \mathrm{Kg} / \mathrm{patch}$ ). Two different drying models (the simple exponential model (Lewis, 1921) and Henderson and Pabis's model (1961)) were also examined for describing the drying data. The obtained results showed that:

1- Rapid moisture removal from rough rice was obvious particularly at higher levels of heating surface temperature and lower grain feed rate.

2- For all levels of heating surface temperature, as the exposure time increased, the difference between the grain bulk temperature and the cylinder surface temperature decreased.

3- Both studied models satisfactorily described the drying behavior of high moisture rough rice as indicated from the high coefficient of determination $\left(R^{2}\right)$ of the two models. However, Lewis's model could be considered most proper for describing the drying behavior of rough rice.

4- Heating surface temperature of $115^{\circ} \mathrm{C}$ with grain feed rate of $3 \mathrm{Kg} /$ patch recorded the highest quality of milled rice.
\end{abstract}

\section{INTRODUCTION}

Rice is presently one of the most important grains in the world with one fourth of the population totally depending on it as a major stable food. Considerable research has been conducted to improve rice milling quality through improved cultural practices, and optimization of harvesting and drying operations (Lu and Siebnomergen 1995).

In order to reduce the grain moisture content to the safe storage level after harvest, the rough rice is typically dried using convective heated air, which is a slow process because heated air at a relatively low temperature must be used to avoid or minimize lowering the rice milling quality. The convective drying process is normally not able to kill the insects and fungi infested rough rice due to the relatively low air temperature. It would be ideal 
to develop a drying method that can be used for simultaneous drying and disinfestations of harvested rough rice with high milling quality. The developed method should also be used to preserve the grain from physical and chemical changes induced or supported by excess moisture (Abe et al., 1992; Parti, 1993 and El-Kholy and Tharwat, 2008).

Heat sterilization and accelerated drying of high moisture rough rice as a method of drying and conditioning has been tried through a limited number of studies. There is evidence in the literature that, conduction heating of high moisture fresh paddy using high temperature for short time, as a method of drying and conditioning could be beneficial in terms of rapid drying, improved milling quality and possible destruction of microorganisms. This technique may be particularly useful to over-com the problem of quality deterioration of high moisture rough rice following the mechanical harvest (El-Kholy, 1998).

The present study aims to test and evaluate the use of hightemperature short time conduction heating technique for drying and sterilization of high moisture rough rice. In addition, the effects of heating treatment on the grain quality and milling potential were also investigated immediately after the drying process.

\section{MATERIALS and METHODS}

\section{Materials:}

Freshly harvested rough rice used for the experimental work was a short grain variety (sakha 101) which harvested from the experimental farm of the Rice Mechanization Center (R.M.C) at Meet El-Dyba, Kafr El-Sheikh Governorate during 2012 rice harvesting season.

\section{Equipment and Test Procedure}

An experimental scale rotary heating unit developed by El-Sahrigi et al. (1999) was used for the experimental work. The dryer consists of a rotary cylinder $(0.6 \mathrm{~m}$ diameter and $0.2 \mathrm{~m}$ long $)$ made of $1 \mathrm{~mm}$ galvanized iron sheet enclosed by a fixed insulated cylinder $(0.8 \mathrm{~m}$ diameter and $0.3 \mathrm{~m}$ long). One side of the rotary cylinder connected to a driving mechanism consists of $0.15 \mathrm{~m}$ diameter steel flange fixed to the side cover of the rotary cylinder and welded to a steel bar riding with a heavy duty ball bearing. A $0.5 \mathrm{Kw}$ low speed motor with different sizes of bullies was used for power supply and speed control of the rotary cylinder. The other side of the rotary cylinder serves as an inlet for rough rice samples through a $0.1 \mathrm{~m}$ diameter center hole. The heat treated rice discharged through a performed removable sector of the cylinder bottom.

For heating and temperature control of the conduction heating rotary unit, two kW electric resistance heaters were placed at the inner surface of the fixed insulted cylinder (between the rotary cylinder and the insulted exterior cylinder) to heat the surface of the rotary cylinder. The surface temperature of the rotary cylinder could be raised up to $175^{\circ} \mathrm{C}$ and maintained within $\pm 1^{\circ} \mathrm{C}$ using a precise digital thermostat controlled by an electric contactor as shown in Fig. (1). 


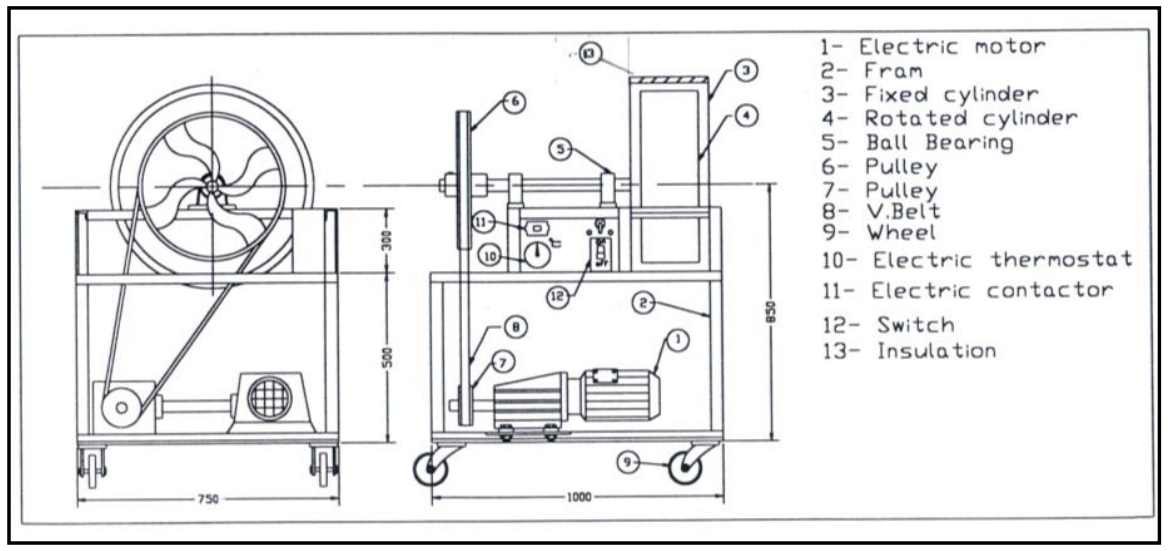

Fig (1): Schematic diagram for the conduction heating unit

\section{Testing Conditions:}

\begin{tabular}{|l|l|}
\hline Experimental treatments & Levels of treatments \\
\hline Initial grain moisture content & $21 \pm 1 \%(w . b)$. \\
\hline Heating surface temperature & $105,115,125,135$ and $145^{\circ} \mathrm{C}$ \\
\hline Grain feed rate & 2.5 and $3 \mathrm{~kg} /$ patch \\
\hline
\end{tabular}

\section{Experimental Measurements:}

\section{Determination of rice moisture content:}

The moisture content of the heat treated rough rice samples were measured by the standard air oven method. at $130^{\circ} \mathrm{C}$ for $16 \mathrm{~h}$ as recommended by El-Sahrigi et al. (1999).

Temperature of the rotary cylinder surface

The remote-type infra-red spot thermometer model (HT-11) was used to measure the rotary cylinder surface temperature during the rotation process as shown in Fig. (2).

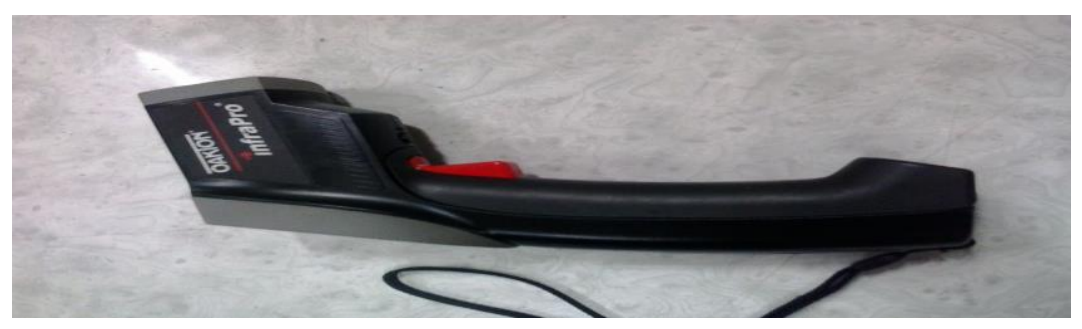

Fig (2): The spot type infra red thermometer. 
Bulk temperature of the heat-treated rough rice:

The temperature of rough rice bulk heated by the studied heating method was immediately measured at the end of each experimental run. The discharged rough rice was received in an insulted glass cylinder and the sensing prop of a one point temperature meter model (A.W. SPERRY DM8600 , Taiwan) with rang of 0 to $400^{\circ} \mathrm{C}$ was inserted through the rough rice bulk until reaching a constant reading as shown in Fig. (3).

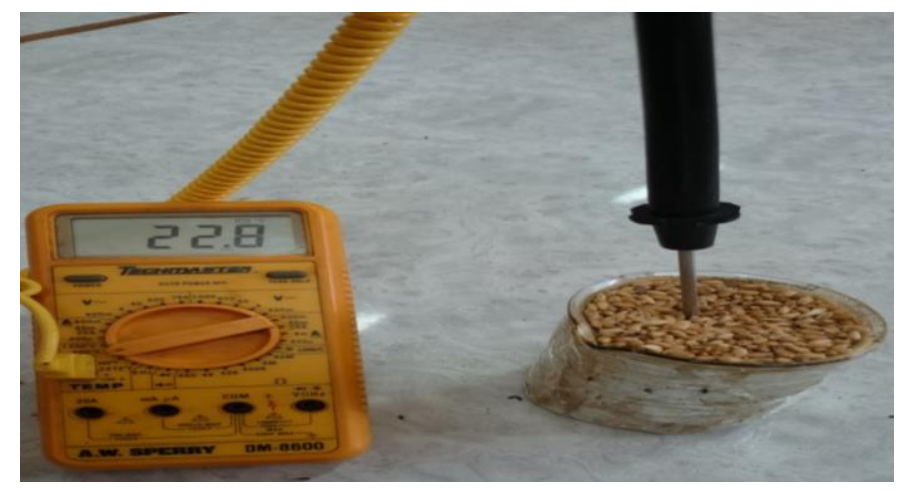

Fig (3): The one point digital temperature meter.

\section{Tests to Evaluate Grain Quality:}

The quality evaluation tests for this study may be assessed as follow:

\section{1-Fungal colony counts:}

The spread plate method recommended by Flannigan, (1977) was used to determine the change in fungal colony count in paddy samples after each experimental run.

\section{2-Grain crack percentage:}

Grain crack percentage was determined according to the method used by (El-Kholy, 1998). For each treatment total of 100 grains were manually dehusked. The resulting brown rice was inspected using the reflection type crack meter.

\section{3-Milling tests:}

The dried rough rice samples at final moisture content level of about $14 \% \pm 1$ (w.b.). were used for the milling tests. The milling quality of rough rice samples were evaluated in terms of whiteness degree and percentage of broken rice. For each test $125 \mathrm{gm}$ of air-dried rough rice samples was passed through a Satake rubber roll husker (model THU35A) with clearance adjusted to give about $90 \%$ brown rice in one pass. The resulting brown rice was poured into the polishing chamber of the satake rice polisher model (SKDDBKK) which was operated automatically for $30 \mathrm{sec}$ in each test. For separating head rice from the broken, a laboratory grader model (TRG-05) was utilized. Broken percentage of milled rice was measured for each treatment. 
The whiteness degree of milled rice samples was measured using a Kett whiteness meter (model C-300) as shown in Fig. (4).

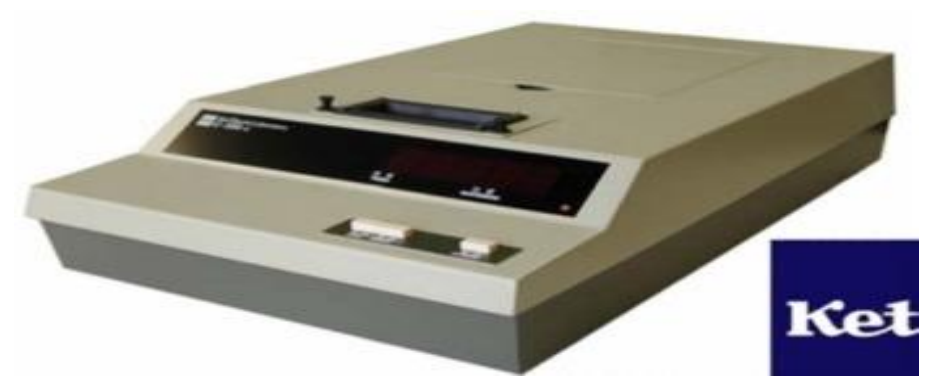

Fig. (4): The grain whiteness meter

Theoretical analysis of the drying process:

To find the most convenient drying models describing the drying behavior of rough rice under the studied ranges of the experimental variables used for this study, Two different drying models were examined to fit the drying data, the simple exponential model (Lewis, 1921) and the modified simple exponential model (Henderson and Pabis, 1961).

The equation representing the simple exponential model was represented as follow:

$$
M R=\frac{M-M_{e}}{M_{O}-M_{e}}=\exp \left(-k_{L} t\right)
$$

Where:

$M R$ : Moisture ratio, dimensionless

$M$ : Moisture content, (d.b), $\mathrm{kg}$ water $/ \mathrm{kg}$ dry solid.

$M_{e}$ : Equilibrium moisture content.

$M_{o}$ : Initial moisture content, (d.b), $\mathrm{kg}$ water $/ \mathrm{kg}$ dry solid.

$t:$ Time, $\min$

$k_{L}:$ The drying constant, min-1.

While, the equation representing the Henderson and Pabis's model was modified to the form:

$$
M R=a \exp \left(-k_{H} t\right)
$$

Where:

$M R$ : Moisture ratio, dimensionless

$t$ : Time, $\mathrm{m}$

$k_{H}$ : The drying rate constant, min-1. 
$a$ : Experimental constants, dimensionless.

he moisture ratio is usually expressed as:

$$
M R=M-M_{e} / M_{o}-M_{e}
$$

However, there is no information available about the equilibrium moisture content of rough rice in a temperature range of 105 to $145^{\circ} \mathrm{C}$ when the air relative humidity is very low. In this case, the rough rice samples will be bone dried after prolonged heating under such conditions. There for, for both models, the moisture ratio was approximated by dropping the equilibrium moisture content term and thus the moisture ratio could be simplified to ( $\frac{M}{M_{o}}$ ), as reported by (El-Kholy, 1998; Yaldiz and Ertekin, 2001; Sacilik and Unal, 2005 and Doymaz, 2004).

\section{RESULTS AND DISCUSSION}

\section{Change in grain moisture content:}

A typical plot showing the change in grain moisture contents as related to drying temperature during the conduction heating of high moisture rough rice is illustrated in Fig. (5).As shown in the Figure (5), rapid moisture removal from rough rice was obvious particularly at higher levels of heating surface temperature and lower grain feed rate. Also, the reduction rate of grain moisture content was higher for the grain feed rate of $2.5 \mathrm{Kg} /$ patch in compression with the feed rate of $3 \mathrm{Kg} /$ patch. This is may be attributed to more contacting of grain surface with the heating surface of the rotary cylinder which increased the grain bulk temperature and the corresponding moisture reduction rate.
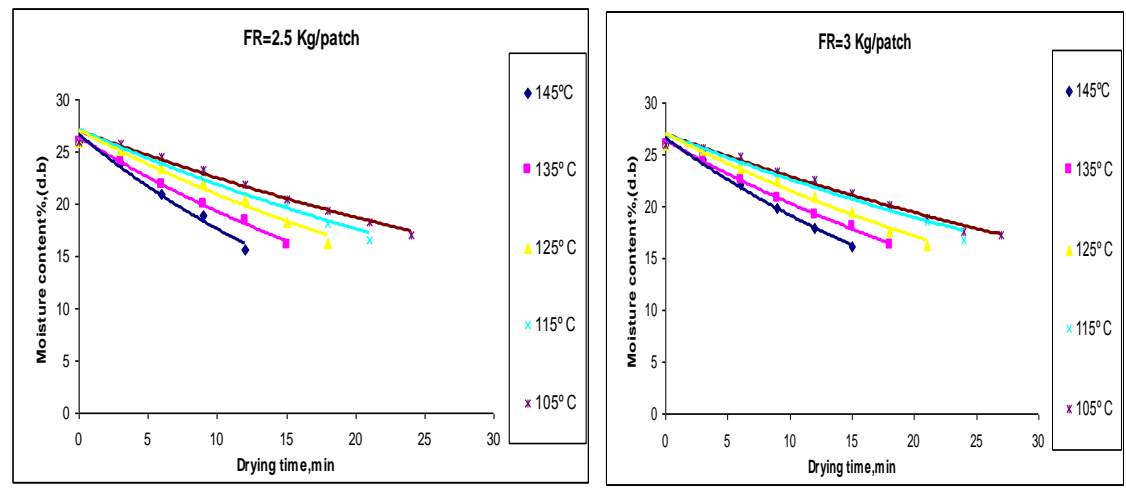

Fig (5): Change in grain moisture content as related to drying time, at different heating surface temperature and different grain feed rates. 


\section{Change in grain bulk temperature}

A typical plot showing the change in grain bulk temperature as related to heating surface temperature for both grain feed rates (2.5 and $3 \mathrm{Kg} / \mathrm{patch}$ ) are illustrated in Fig (6). As shown in the figure the grain bulk temperature was lower during the early stage of heating process and it was increased with longer exposure duration. It should be maintained that all treatments followed the same pattern One may say that, during the early stage of heating the temperature difference between the grain bulk and the heating surface temperature is relatively high which causes higher rate of heat transfer from the cylinder surface to the grain which cause in turn higher rate of grain bulk temperature rise. In general, for all levels of heating surface temperature, as the exposure time increased, the difference between the grain bulk temperature and the cylinder surface temperature decreased and the heating rate also decreased.
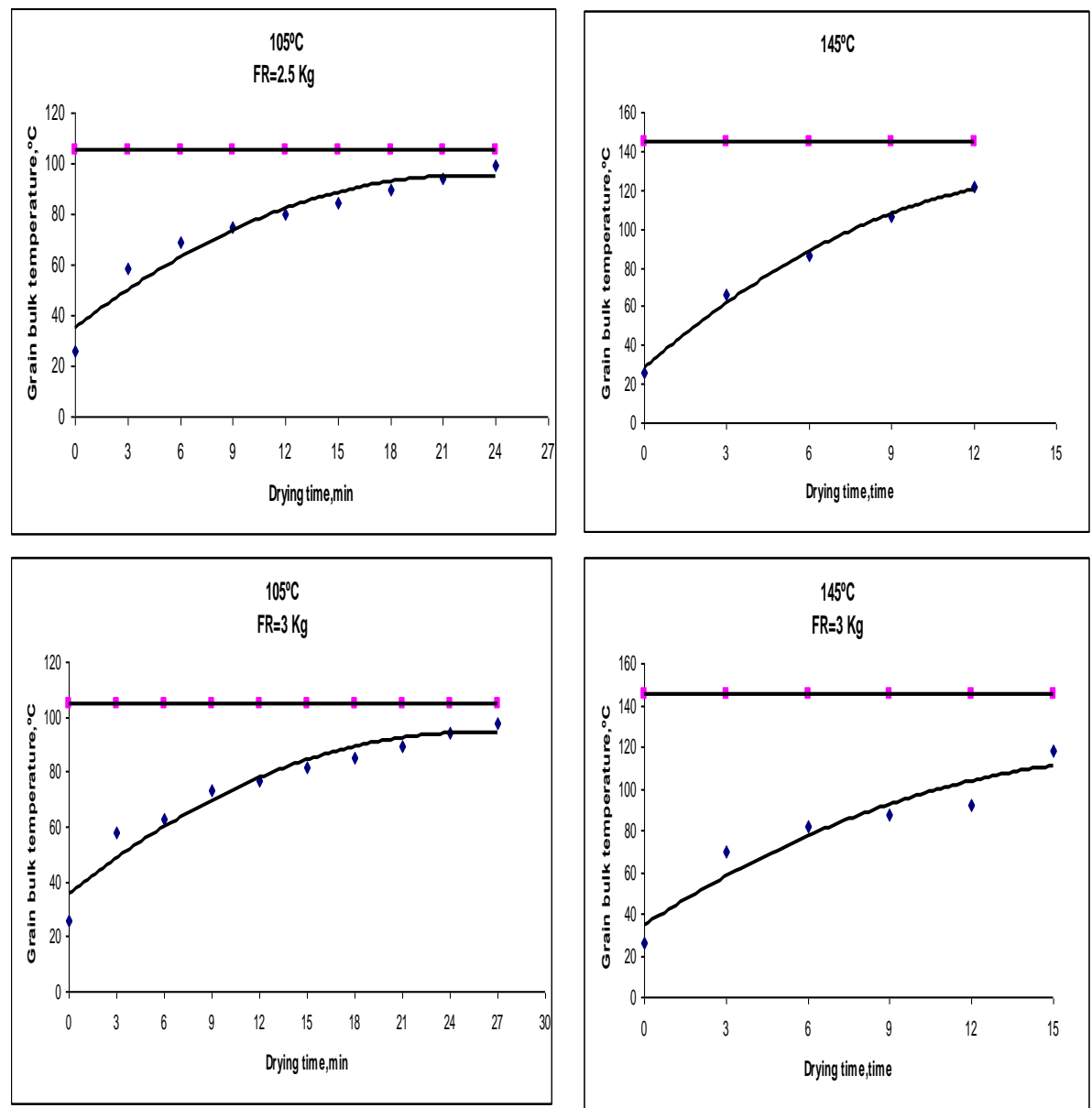

Fig (6): A typical plot of the change in grain bulk temperature as related to drying time. 
Analysis of thin layer drying based on Lewis's model:

The values of drying constant $\left(\mathrm{K}_{\mathrm{L}}\right)$ for the simple drying model (1) which were obtained from the exponential relationship between the grain moisture ratio (MR) and the drying time (t) are listed in table (1).

Table (1): Values of drying constant $\left(\mathrm{K}_{\mathrm{L}}\right)$ for Lewis's model:

\begin{tabular}{|l|c|c|}
\hline Drying constant $\left(\mathrm{K}_{\mathrm{L}}\right)$ & \multicolumn{3}{|c|}{ Feed rate, (Kg/patch) } \\
\cline { 2 - 3 } Drying temperature, ㅇ & $\mathbf{2 . 5 K g}$ & $\mathbf{3 K g}$ \\
\hline 105 & 0.0162 & 0.0146 \\
\hline 115 & 0.0188 & 0.0156 \\
\hline 125 & 0.0229 & 0.0203 \\
\hline 135 & 0.0301 & 0.0251 \\
\hline 145 & 0.0388 & 0.0309 \\
\hline
\end{tabular}

As shown in table (1), the drying constant $\left(\mathrm{K}_{\mathrm{L}}\right)$ increased with the increase of drying temperature, while it was lower for the grain feed rate of 3 $\mathrm{Kg}$ in comparison with the grain feed rate of $2.5 \mathrm{Kg}$ at all levels of cylinder surface temperature. These results are in agreement with that obtained by (El.Kholy 1998).

The applicability of Lewis's model in simulating the drying data:

Fig (7) shows the observed and the calculated values of grain moisture content at the minimum and maximum levels of drying temperature. The results indicated that, Lewis's model can satisfactorily describe the drying behavior of rough rice during conduction heating process. The results indicated that, Lewis's model describe the drying behavior of rough rice as indicated from the high values of coefficient of determination $\left(R^{2}\right)$ and low values of standard error (SE) as shown in table (2). 
J. Soil Sci. and Agric. Eng., Mansoura Univ., Vol. 5 (3), March, 2014
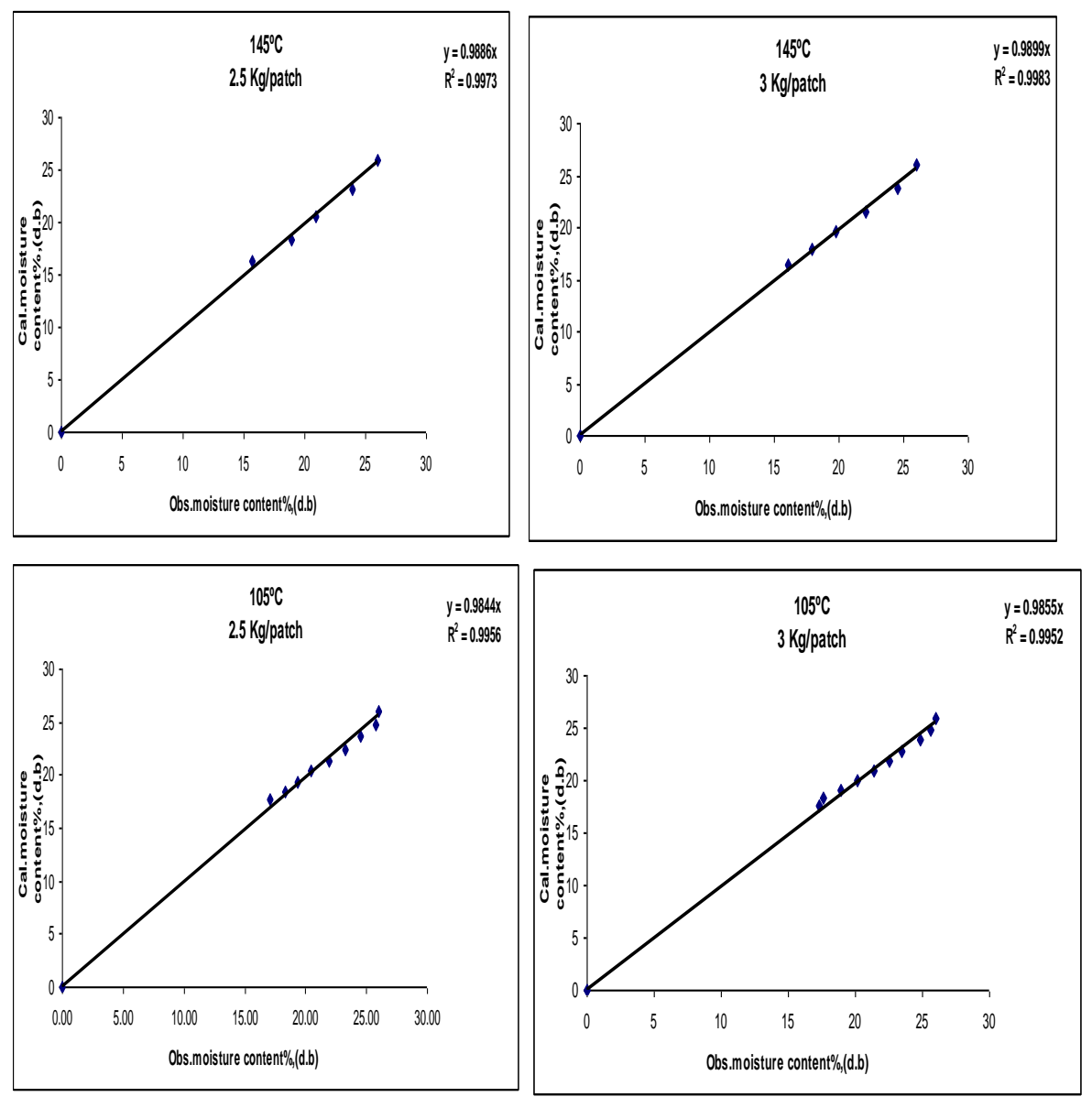

Fig (7): The observed, (obs) and calculated, (cal) moisture content of rough rice using the Lewis's model.

Table (2): Values of coefficient of determination $\left(R^{2}\right)$ and standard error (SE) for Lewis's model.

\begin{tabular}{|l|c|c|c|c|}
\hline \multirow{2}{*}{ Drying temperature ㅇ } & \multicolumn{2}{|c|}{$\mathbf{2 . 5} \mathbf{~ K g} / \mathbf{p a t c h}$} & \multicolumn{2}{c|}{ 3 Kg/patch } \\
\cline { 2 - 5 } & $\mathbf{R}^{\mathbf{2}}$ & $\mathbf{S . E}$ & $\mathbf{R}^{\mathbf{2}}$ & $\mathbf{S . E}$ \\
\hline 105 & 0.9956 & 0.4984 & 0.9952 & 0.4909 \\
\hline 115 & 0.9929 & 0.6754 & 0.9942 & 0.5793 \\
\hline 125 & 0.994 & 0.6607 & 0.9953 & 0.5434 \\
\hline 135 & 0.9989 & 0.3132 & 0.9991 & 0.2553 \\
\hline 145 & 0.9973 & 0.5266 & 0.9983 & 0.3801 \\
\hline
\end{tabular}


Analysis of grain drying behavior using Henderson and Pabis's model:

The value of drying constants $\left(\mathrm{K}_{\mathrm{H}}\right)$ for Henderson and Pabis's model which obtained from the exponential relationship between the grain moisture ratio (MR) and the drying time (t) are listed in table (3).

Table (3): Values of drying constant $\left(\mathrm{K}_{\mathrm{H}}\right)$ for Henderson and pabis's model:

\begin{tabular}{|l|c|c|}
\hline Drying constant $\left(\mathbf{K}_{\mathbf{H}}\right)$ & \multicolumn{2}{|c|}{ Grain feed rate, (Kg/patch) } \\
\hline \multirow{3}{*}{ Drying temperature, ${ }^{\circ} \mathbf{C}$} & $2.5 \mathrm{Kg}$ & $3 \mathrm{Kg}$ \\
\hline 105 & 0.0184 & 0.0165 \\
\hline 115 & 0.0216 & 0.0177 \\
\hline 125 & 0.0259 & 0.0228 \\
\hline 135 & 0.0314 & 0.0261 \\
\hline 145 & 0.0416 & 0.033 \\
\hline
\end{tabular}

The results in table (3) showed that, the drying constant $\left(\mathrm{K}_{\mathrm{H}}\right)$ increased with the increase of drying temperature, while it was decreased with the increase of grain feed rate.

However, the values of drying constant (A) showed no trend for both studied grain feed rate and it was ranged from 1.0138 to 1.0423 for the feed rate of $2.5 \mathrm{Kg}$ and from 1.0129 to 1.0367 for the feed rate of $3 \mathrm{Kg}$ with an average of 1.03178 and 1.02948 for feed rate of 2.5 and $3 \mathrm{Kg} /$ patch respectively, as shown in table (4)

Table (4): Values of drying constant (A) for Henderson and pabis's model:

\begin{tabular}{|l|c|c|}
\hline Drying constant (A) & \multicolumn{2}{|c|}{ Grain feed rate, (Kg/patch) } \\
\cline { 2 - 3 } Drying temperature, oC & $\mathbf{2 . 5 K g}$ & $\mathbf{3 K g}$ \\
\hline 105 & 1.0378 & 1.0361 \\
\hline 115 & 1.0423 & 1.0367 \\
\hline 125 & 1.0405 & 1.039 \\
\hline 135 & 1.0138 & 1.0129 \\
\hline 145 & 1.0245 & 1.0227 \\
\hline Avr & 1.03178 & 1.02948 \\
\hline
\end{tabular}

The applicability of Henderson and Pabis's mode in simulating the drying data:

The results indicated that, Henderson and Pabis's model can also describe the drying behavior of rough rice as indicated from the high values of coefficient of determination $\left(R^{2}\right)$ and low values of standard error (SE) as shown in table (5). 
J. Soil Sci. and Agric. Eng., Mansoura Univ., Vol. 5 (3), March, 2014

Table (5): values of coefficient of determination $\left(R^{2}\right)$ and standard error (SE) for Henderson and pabis's model:

\begin{tabular}{|l|c|c|c|c|}
\hline \multirow{2}{*}{ Drying temperature ${ }^{\circ} \mathbf{C}$} & \multicolumn{2}{|c|}{$\mathbf{2 . 5} \mathbf{~ K g}$} & \multicolumn{2}{c|}{$\mathbf{3 ~ K g}$} \\
\cline { 2 - 5 } & $\mathbf{R}^{\mathbf{2}}$ & $\mathbf{S . E}$ & $\mathbf{R}^{\mathbf{2}}$ & $\mathbf{S . E}$ \\
\hline 105 & 0.9971 & 0.4356 & 0.9967 & 0.4375 \\
\hline 115 & 0.9939 & 0.6648 & 0.9951 & 0.2636 \\
\hline 125 & 0.9947 & 0.6604 & 0.9963 & 0.5152 \\
\hline 135 & 0.9989 & 0.3176 & 0.993 & 0.2385 \\
\hline 145 & 0.9993 & 0.5429 & 0.9986 & 0.361 \\
\hline
\end{tabular}
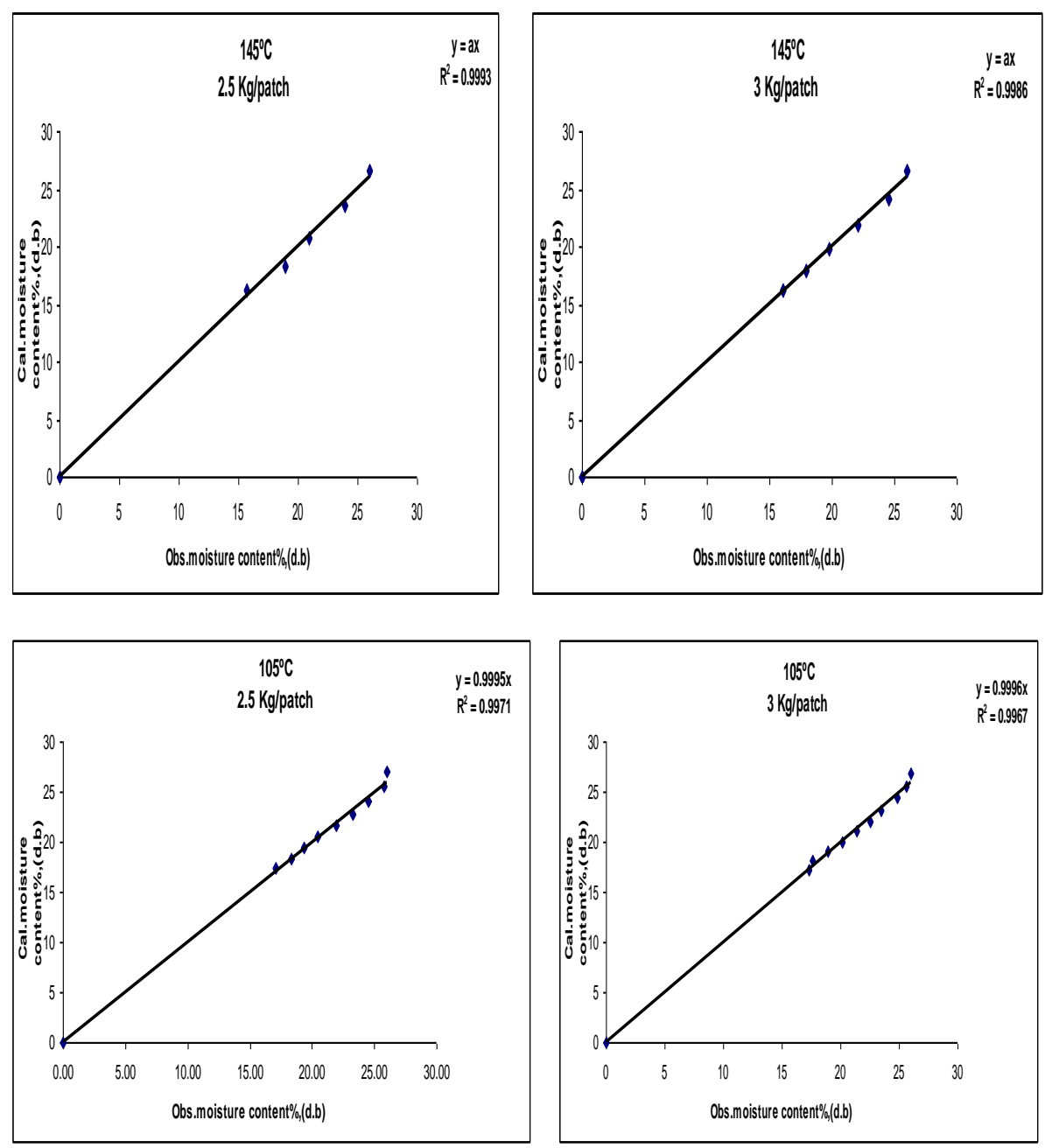

Fig. (8): The observed, (obs) and the calculated, (cal) moisture content of rough rice using the Henderson and Pabis's model. 


\section{A comparison study between the two studied models:}

In general, both studied models could satisfactorily describe the drying behavior of high moisture rough rice as indicated from the high levels of correlation coefficients $\left(R^{2}\right)$ of the two models. However, the Lewis's model could be considered most proper for describing the drying behavior of rough rice due to more simplicity of this model in calculation and analysis.

\section{Tests to evaluate grain quality}

\section{Fungi inactivation during conduction heating process:}

Fig (9) illustrates the change in fungal mortality level as related to the heating surface temperature for different grain feed rates. It was obviously showed that, the high temperature conduction heating reduced the fungal load in high moisture rough rice in an effective manner. This effectiveness was obvious as the heating surface temperature increased and the grain feed rate decreased.

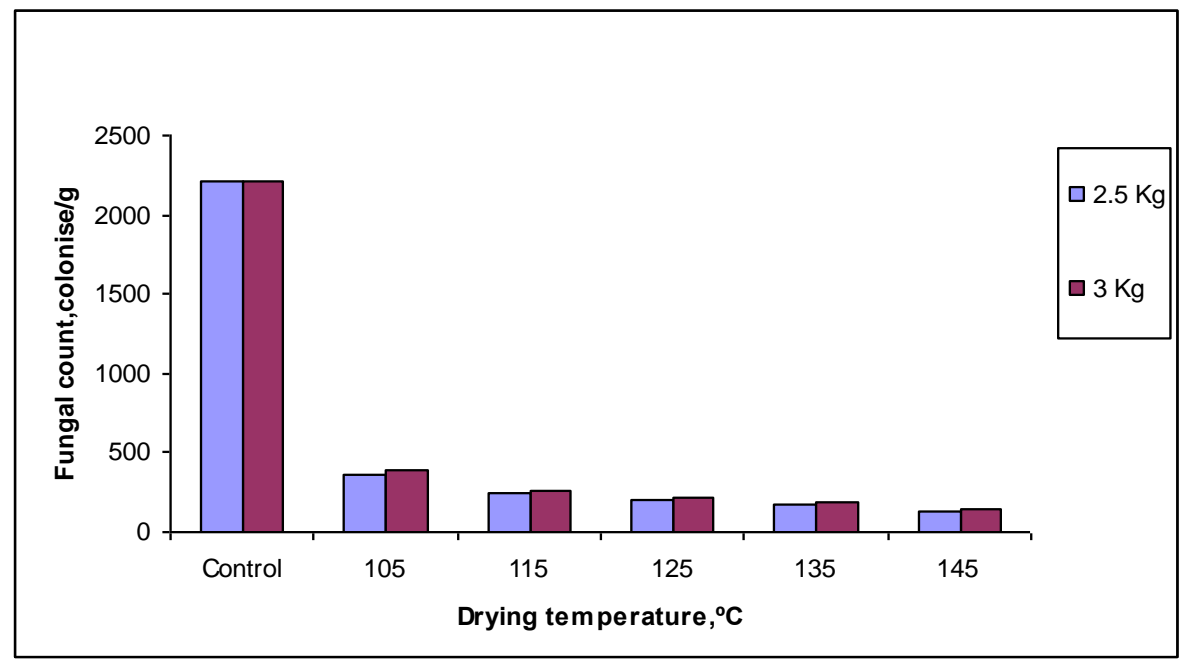

Fig (9): Change in fungal mortality level as related to cylinder surface temperature at different levels of grain feed rates.

\section{Effect of heat treatment on grain crack percentage:}

The effect of heat treatments on grain crack percentage is presented in Fig. (10). As shown in the figure the heat treated rough rice showed a fluctuation in grain crack percentage depending upon heating surface temperature (Ts) and grain feed rates (FR). At lower levels of cylinder surface temperatures, the grain crack percentage was lower. However, the lower level of grain feed rate showed higher grain crack percentage in comparison with the higher levels, due to more exposure of grains to the heat treatment. 


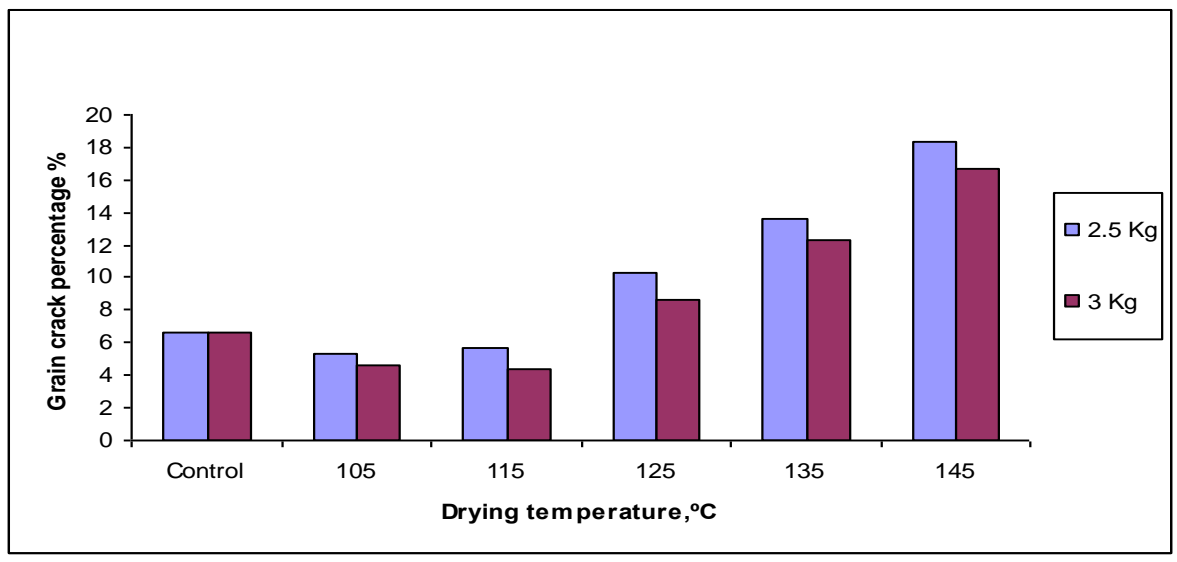

Fig. (10): The change in grain crack percentage as related to the heating surface temperature for different grain feed rates.

\section{Effect of heat treatment on grain broken percentage:}

The effects of various heat treatments on grain broken percentage are summarized in Fig. (11). As shown in the Figure heat-treated rough rice showed a reduction in broken percentage as the cylinder heating surface temperature decreased and grain feed rate increased. Similar observations have been conformed in the past during the high temperature conduction heating of high moisture rough rice by several researchers (Abe et al. 1992; El-Kholy, 1998 and El-Sahrigi et al. 2000).

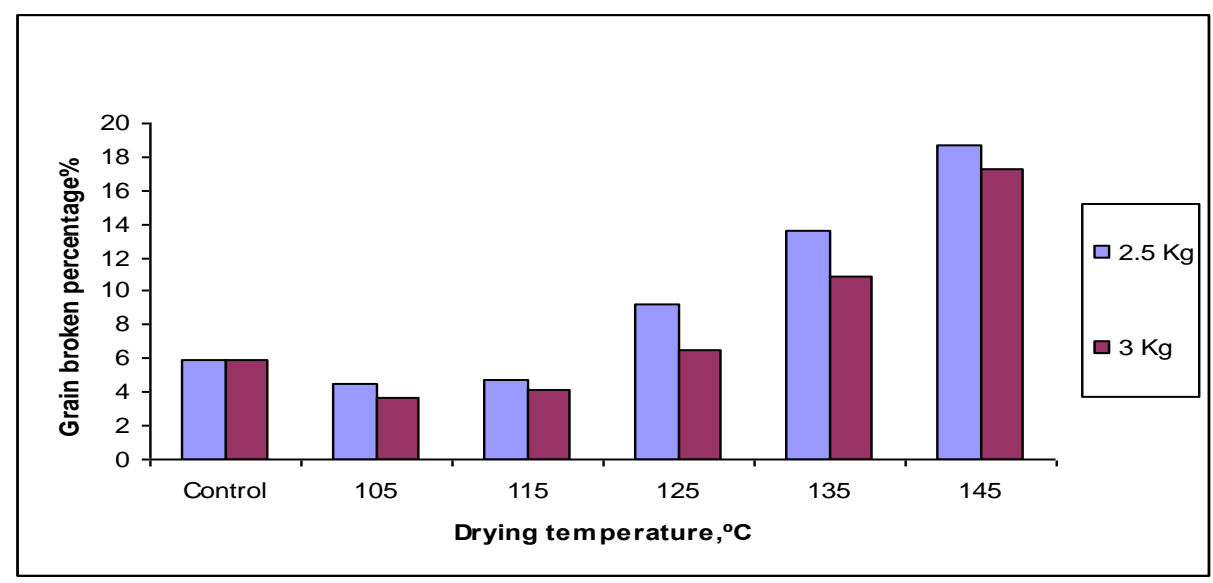

Fig. (11): The change in grain broken percentage as related to the heating surface temperature of different grain feed rates. 
The reduction in broken percentage of the heat-treated grain exposure to lower level of heating surface temperature and higher grain feed rate of 3 $\mathrm{Kg} /$ patch could be attributed to the gelatinization of starch granules and cementing part of grain fissures as indicated by (El-Sahrigi et al. 1999).

\section{Effect of heat treatment on milled rice whiteness:}

As shown in fig (9), heat-treated rough rice samples yielded milled rice slightly yellowish in appearance in comparison with the unheated control samples. This change in color could be attributed to the non- enzymatic browning and/or the diffusion of coloring pigments of the rice hull and bran to the endosperm caused by exposure of the grain to high levels of temperature. These results agreed with the results obtained by (Khan et al. 1974 and ElKholy 1998).

In general, the change in grain color was less severs for milled rice produced from rough rice samples exposed to lower heating surface temperature, higher grain feed rate and shorter exposure time.

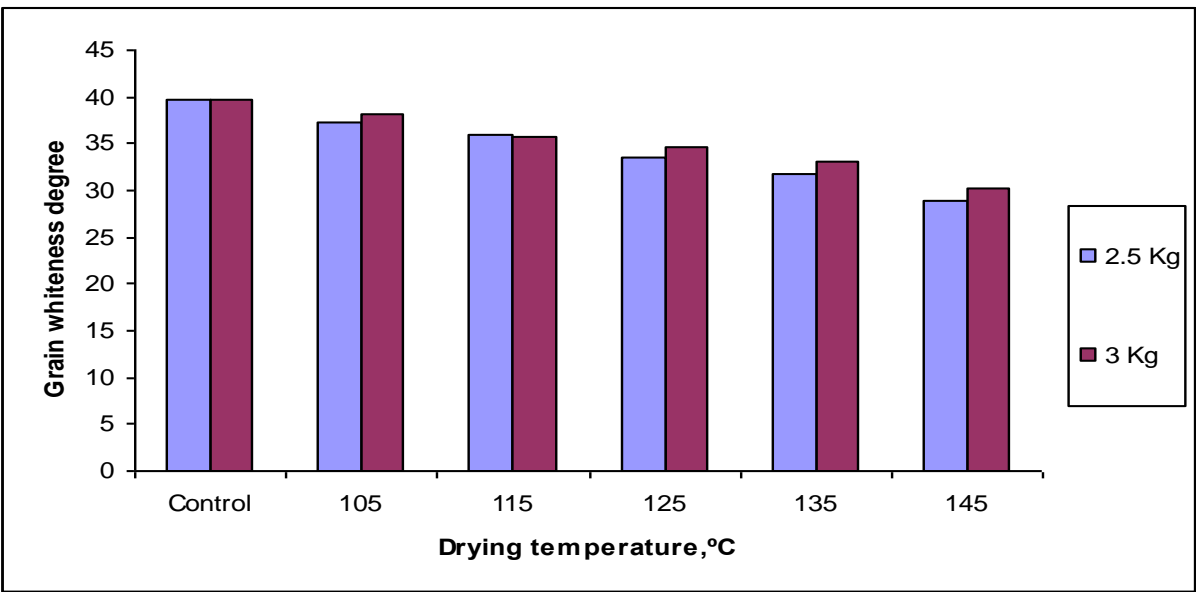

Figure (12): Whiteness degree of heat treated rough rice during conduction heating process in comparison with the natural dried sample.

\section{CONCLUSIONS}

1- Rapid moisture removal from rough rice was obvious particularly at higher levels of heating surface temperature and lower grain feed rate.

2- For all levels of heating surface temperature, as the exposure time increased, the difference between the grain bulk temperature and the cylinder surface temperature decreased.

3- In general, both studied models satisfactorily describe the drying behavior of high moisture rough rice as indicated from the high coefficients of determination $\left(R^{2}\right)$ of the two models. However, the Lewis's model could be 
considered most proper for describing the drying behavior of rough rice this may be due to more simplicity of this model in calculation and analysis.

4- As the heating surface temperature increased and the grain feed rate decreased the fungal mortality level relatively decreased, the grain crack percentage increased, the grain broken percentage increased and the grain whiteness decreased.

5- The heating surface temperature of $115^{\circ} \mathrm{C}$ with grain feed rate of $3 \mathrm{Kg}$ /patch recorded the highest grain surface sterilization and the best quality of milled rice.

\section{REFERENCES}

Abe, T., Y. Hikida, C. E. Ofoche and J. Yamashita. (1992). Effect of drying parameters on quality of artificially dried rough rice. Agric. Mech. In Asia, 23(4):42-46.

Doymaz, I (2004). Convective air drying characteristics of thin layer carrots. Journal of Food Engineering, 61, 359-364.

El-Kholy, M.M, (1998) Conditioning and aeration of high moisture paddy under different storage conditions. Unpublished, Department of Agri. Eng., Fac. of Agric., Mansoura univ.

El-Kholy, M.M. and A. Tharwat, (2008). Accelerated drying and stabilization of canola seeds and oil. Egypt J. of agric. Sci. Mansoura Univ., 33(11), November.

EL-Sahirigi, A. F.; A.M. Matouk; H.EL-Abd Alla and M.M. El- Kholy. 1999. Accelerated partial drying and sterilization of high moisture rough rice. Egypt j. Agric. Res., 78(2):977-991.

El-Sahrigi, A. F.; A. M. Matouk; M. M. Ibrahim; H. El. Abd-alla and M. M. ElKholy. (2000). Storage of conditioned high moisture paddy under different storage system. Egypt J. Agric. Res., 78(4) PP. 1715-1735.

Flannigan, B. 1977. Enumeration of fungi and assay for ability to degrade structural and components of grain. In Biodeterioration investigation techniques (ed. H. Walters) London, Applied Science Publishers, pp. 185-199.

Henderson, S.M. and S. Pabis, (1961). Grain drying theory. temperature effect on drying coefficient. J. agric. Engng. Res., 6(31), 169-174.

Khan, S.A.J., S.B. Mathur and P. Neergaard, 1974. Survery of new seedborne organisms of Pakistan. Seed Sci. \& Technol., 2; 477.479.

Lewis, W.K. (1921). The rate of drying of solid materials j. of Ind. Eng. Chem. 13(5): 427-432.

Lu. R. and T. J. siebnomergen (1995). Correlation of head rice yield to select physical and mechanical properties of rice kernels. Transaction of the ASAE, 38(3): 889-894).

Parti, M. (1993). Selection of mathematical models for drying grain in thinlayers. J. Ag. Eng. Res.54:339-352. 
Sacilik, K. and G. Unal (2005). Dehydration characteristics of kastamonu garlic Slices. Bio-systems Engineering, 92: (2), 207-215.

Yaldiz. O.; C. Ertekin and H.L. Uum (2001). Mathematical modelling of thin laver solar drying of Sultana grapes. Energy, 26: $457-465$.

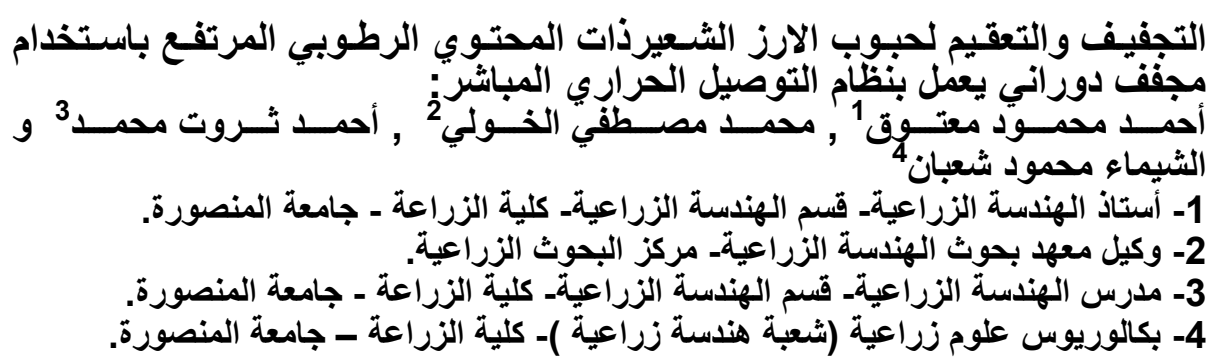

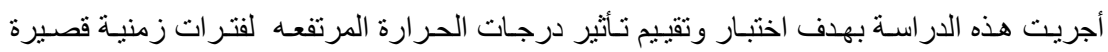

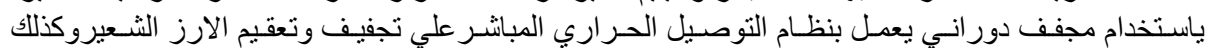
تأثير ها علي خصائص الضرب النياب لمحصول الارز.

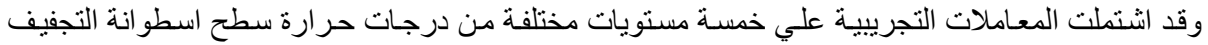

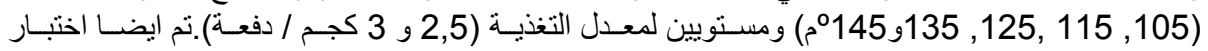
نموذجين مختلفين من معادلات التجفيف في وصف منحنيات التجفيف و التتبؤ (Lewis's model - Henderson and Pabis's model) بالمحتوي الرطوبي للحبوب اثناء عملية التجفيف.

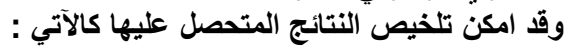

1- لوحظ انخفاض سريع للمحتوى الرطوبي للحبوب عند المستويات المرتفعة من درجات الحرارة المستخدمة و المنففضة من معدل التغذية.

2- بزيادة زمن التجفيف انخفض الفرق بنفية بين درجة حرارة سطح اسطو انة التجفيف ودرجة حرارة الحبوب و وذلك عند جميع مستويات الحرارة التي تم دراستها.

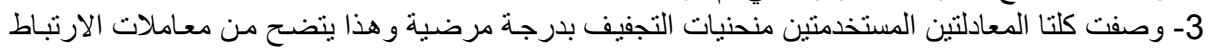

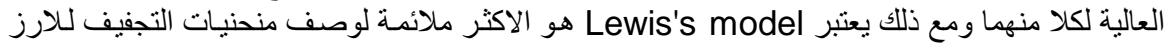

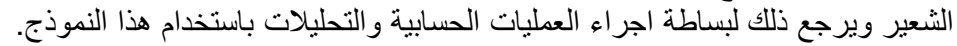

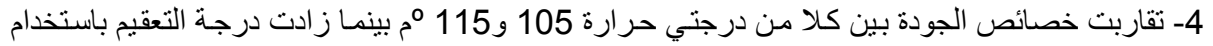

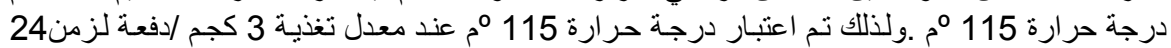
دقيقة للمتغير ات المثلي للحصول علي اعلي جودة لخصائص الضرب وتمبر وتعقيم الحبوب.

كلية الزراعة - جامعة المنصورة كلية الزراعة - جامعة قناه السويس
قام بتحكيم البحث

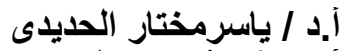
أ.د / شُريف عبد الحق رضوان الحبدى 